\title{
Functional outcomes after treatment of traumatic brachial plexus injuries: clinical study
}

\author{
Yavuz Aras, M.D, Aydın Aydoseli, M.D, Pulat Akın Sabancı, M.D, \\ Mehmet Osman Akçakaya, M.D, Görkem Alkır, Murat İmer, M.D \\ Department of Neurosurgery, Istanbul University Istanbul Faculty of Medicine, Istanbul
}

\begin{abstract}
BACKGROUND: The aim of this study is to evaluate functional outcome and quality of life using statistically validated tools.

METHODS: Participating patients were called and asked questions from the Short Form 36 (SF-36), the Disability of the Arm, Shoulder and Hand (DASH) questionnaire, a pain scale and an additional question on their satisfaction with surgery.

RESULTS: A total of 33 patients were operated by a single surgeon (MI) between 1997 and 2010 at the Neurosurgery Department of Istanbul School of Medicine. Three of these patients refused to participate and three other patients were excluded, leaving 27 patients, with an average follow-up of 79,6 months, for review. The most common cause of traumatic brachial plexus injuries (TBPI) was motor vehicle accidents. Fourteen patients had isolated supraclavicular injuries and three patients had infraclavicular injuries. The remaining 10 patients' injuries were both supra- and infraclavicular. Avulsion was encountered in three patients. The patients who were operated within the first six months after trauma represented significantly better scores in DASH, SF-36 and pain scale.
\end{abstract}

CONCLUSION: Statistically validated tests like DASH and SF-36 questionnaires are valuable tools for evaluating TBPI patients. Centers specialized in treating TBPI with surgery may use these tests pre- and postoperatively which lead to objective personalized evaluation of patients' subjective symptoms.

Key words: Brachial plexus, functional outcome; nerve injury, quality of life.

\section{INTRODUCTION}

Traumatic brachial plexus injuries (TBPI) tend to occur in young, otherwise healthy and active individuals. While brachial plexus injuries themselves are not fatal, they can cause disability and can be very difficult to reverse. ${ }^{[1]}$ In addition to motor and sensory deficits, they may also cause pain and functional limitations. ${ }^{[2]}$ Over the years, opinions concerning the treatment of lesions of the brachial plexus have changed. [3] The development of microsurgery and associated technology renewed interest in surgical reconstruction, and has given rise to more favorable results in comparison to earlier studies. ${ }^{[3-5]}$

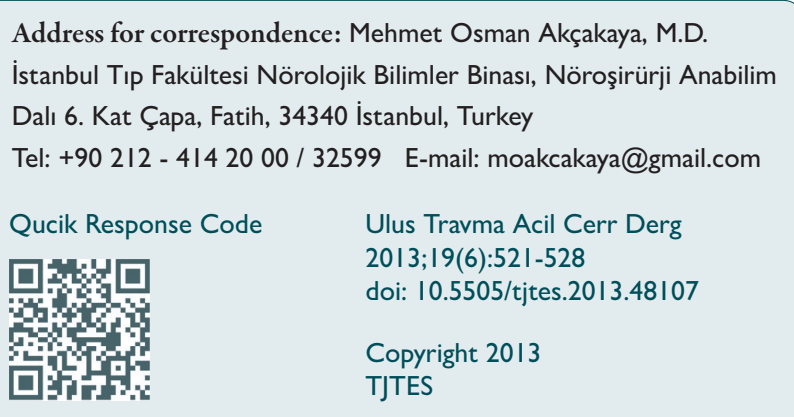

In most of the studies, surgical results were assessed only by means of motor or sensory recovery, ${ }^{[1,6-9]}$ which does not always correlate with functional status. Functional outcomes and quality of life (QOL) were evaluated only in a few series. $^{[2,10,11]}$ The recent development of statistically validated functional and QOL assessment tools has improved the ability of clinicians to quantify these outcomes. ${ }^{[2]}$ According to Kretschmer et al. ${ }^{[1]} 87 \%$ of patients operated for TBPI were satisfied and $83 \%$ would undergo the procedure again. Despite a high satisfaction rate, patients remained considerably disabled and half of the patients were unable to return to work. Thus, there is a discordance between patient satisfaction and disability.

In the present study, the functional outcomes of a TBPI patient series operated by a single surgeon were evaluated by using Short From 36 (SF-36) and the Disability of the Arm, Shoulder and Hand (DASH) questionnaire and by assessing of pre- and postoperative pain. The goal of this study is to present our clinical experience by analyzing the influence of demographic features, injury type, timing of surgery, side and location of injury, preoperative motor examination, surgical approach, technique, and additional injury to QOL with functional outcomes of the TBPI patients by using these scales. 


\section{MATERIALS AND METHODS}

Thirty-three patients underwent surgery to treat a TBPI between 1997 and 2010 in Department of Neurosurgery, İstanbul School of Medicine by a single surgeon (MI). All of the patients were contacted by phone except one, who was deceased secondary to a myocardial infarction three years ago. One other patient had been diagnosed with non small cell lung cancer and was excluded from the study with this additional diagnosis. Another patient experienced a TBPI while falling during a suicide attempt. Hospital records indicated that the patient was diagnosed with major depressive disorder. His answers were thought to be subjective due to his possible ongoing depression. Three patients from the remaining 30 patients refused to participate in the study.

The remaining 27 participant patients were asked to give answers on phone for DASH and SF-36 questionnaires. They were asked to give a number between 0 and 100 for the pain they suffered before the surgery and at the moment of conversation.

The medical records of these 27 patients were reviewed retrospectively for demographic data, location, side, type and mechanism of injury, preoperative and early postoperative neurological status of the patient, surgical technique, presence of avulsion, additional injury, time interval between injury and surgery and electrophysiological findings. Data was recorded in an SPSS spreadsheet (SPSS version I3.0 for Windows; SPSS, Inc., Chicago, IL).

The location of the TBPI was classified as supraclavicular if the injured elements were roots or trunks. It was infraclavicular if cords or main terminal branches were affected. If both supra and infraclavicular elements were affected they were grouped as both.

\section{Questionnaires}

The DASH Outcome Measure is a 30 -item, self-report questionnaire designed to measure physical function and symptoms in people with any of several musculoskeletal disorders of the upper limb. ${ }^{[14]}$ The tool gives clinicians and researchers the advantage of having a single, reliable instrument that can be used to assess any or all joints in the upper extremity. Every question can be answered on a scale from I to 5 and with a total minimum score of 30 and maximum 150. Lower scores indicate better results. ${ }^{[2,12,13]}$ The hand or arm the patient uses to perform a particular activity does not influence the response; answers must be based on the ability to perform the activity, regardless of how the activity was performed.

The SF-36 is a multi-purpose, short-form health survey with only 36 questions. It yields an eight-scale profile of functional health and well-being scores as well as a psychometricallybased physical and mental health summary measures and a preference-based health utility index. It is a generic measure, as opposed to one that targets a specific age, disease or treatment group. Accordingly, the SF-36 has proven useful in surveys of general and specific populations, comparing the relative burden of diseases and in differentiating the health benefits produced by a wide range of different treatments. $[15,16]$ The results are separated into eight subscale profiles; energy and vitality, physical function, social function, role limitations caused by physical problems, role limitations caused by emotional problems, bodily pain, mental health, general perception of health. The results can be demonstrated as physical and mental summary scores. Higher scores indicate better results. ${ }^{[2]}$

For the evaluation of pain that patients suffer, they were asked to give a number from 0 to 100 . The idea was to mimic the Visual Analogue Pain Scale (VAPS) on the phone. All of the questions were asked by a secretary/non-physician in order to eliminate any effect of pressure on the patient's response.

\section{Statistical Analysis}

Data was entered and analyzed using statistical software (SPSS version 13.0 for Windows). The SF-36 results were linearly transformed to a scale of 0 to 100 and were compared with the normative scores of the general population. ${ }^{[17,18]}$

All samples were analyzed using Student's test for parametric data and the Mann-Whitney U-test for non-parametric data. One-way analysis of variance was used for comparing patients in the three injury location subgroups. Spearman's $\rho$ correlation coefficients were calculated between the scores on the decision making question as well as the time delay to surgery and each of the DASH questionnaire, the SF-36 subscales and the pain scale.

\section{RESULTS}

From the $33 \mathrm{TBPI}$ patients who underwent surgery 27 agreed to participate in the study ( 1 patient died, 2 patients were excluded, 3 patients refused to enroll in the study). There were 7 females and 20 males. Their mean age was 31.7 years old (range 10-66 yrs.). The mean time from injury to surgery was 6.6 months (range 2-17 mos.). The mean follow-up period from surgery to the telephone contact was 79.6 months (range 17-150 mos.).

In the current study, the most common cause of TBPI was motor vehicle accidents which was concordant with the previous literature. ${ }^{[1,11]}$ Motor vehicle accidents, pedestrian accidents and penetrating injuries are the major causes of all trauma. Motorcycle accidents, falls and occupational accidents are subsequent causes of BPI (Table I). Associated injuries were encountered in six patients. Two patients had thoracal vertebra fractures, one had spinal epidural hemato$\mathrm{ma}$ at the third cervical vertebra level and a left tibia fracture, 
Table I. Characteristics of TBPI

\begin{tabular}{lc}
\hline Description & No. of patients \\
\hline Type of injury & \\
Motor vehicle accident & 7 \\
Pedestrain accident & 7 \\
Falls & 3 \\
Motorcycle accident & 2 \\
Penetrating injury & \\
$\quad$ Firearm injury & 3 \\
$\quad$ Glass & 2 \\
$\quad$ Knife & 1 \\
$\quad$ Occupational accident & 2 \\
Location of injury & \\
Supracalvicular & 14 \\
Infraclavicular & 3 \\
Both & 10 \\
Avulsion & \\
Present & 3 \\
Absent & 24 \\
Associated injuries* & \\
Spinal fracture & 2 \\
Extremity fracture & 2 \\
Hemopneumothorax & 1 \\
Spinal epidural hematoma & 1 \\
Abdominal trauma & 1 \\
Clavicula fracture & 2 \\
No associated injury & \\
\hline *Some of the patients had multipl additional injuries. & \\
&
\end{tabular}

one had a hemopneumothorax, two patients had clavicular fractures, and one patient had a firearm injury in abdomen and a left radius fracture (Table $\mathrm{I}$ ).

Fourteen patients had isolated supraclavicular and three patients had infraclavicular injuries. The remaining 10 patients' injuries were both supraclavicular and infraclavicular. Three patients were diagnosed with an avulsion.

\section{Surgical Technique}

Patients were operated according to their neurological examination and electromyographic findings. MRI was also used in some of the patients with root avulsions in order to evaluate the presence of meningocele.

All of the patients received general anesthesia during surgery. Operations were done according to the approaches demonstrated in the previous literature. ${ }^{[19,20,21]}$ An anterior approach was selected for all of the cases. ${ }^{[22,23]}$ Exploration of the brachial plexus and external neurolysis were performed in every case.

When a chronically injured nerve is surgically exposed, it is typically scarred and adherent to surrounding tissue. External neurolysis can is a technique in which the nerve is released from its local tethering (Fig. I). And if feasible, the nerve is translocated to a site that is not mechanically traumatized (Fig. 2). This process does not intentionally violate the epineurium and vascular supply of the nerve. ${ }^{[24]}$
Internal neurolysis was added to external neurolysis according to the perioperative observations of the surgeon. If the nerve was found to be extremely compressed and the fascicle was thought to be tighten by adhesions then internal neurolysis was performed. The process of internal neurolysis involves division with or without removal of the external epineurium and then dissection in the plane of investing extrafascicular internal epineurium. Removal of extrafascicular connective tissue is performed, taking care not to enter the fascicular perineurium (Fig. 3). ${ }^{[24]}$

If there was not a defect in the anatomic continuity of the brachial plexus and only nerve compression was found, the operation was finalized by performing neurolysis. If a problem on the continuity of the nerve was detected, end to end
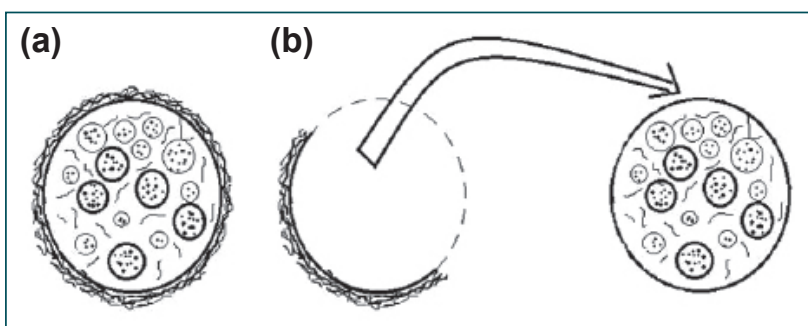

Figure 1. External neurolysis. (a) Nerve contained within surrounding scar. (b) Nerve is dissected from scar in plane around the external epineurium.

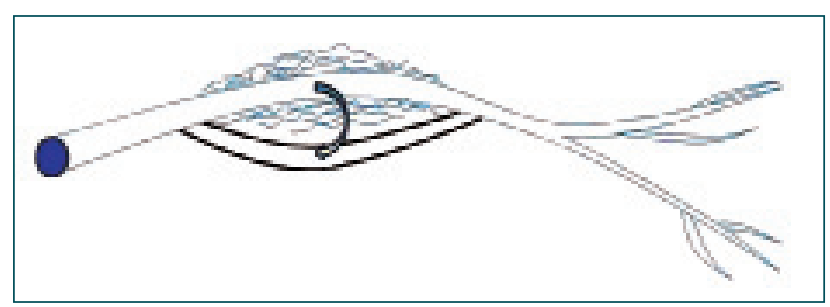

Figure 2. Transposition. Nerve is transposed to a location that is not subject to repetitive mechanical trauma.

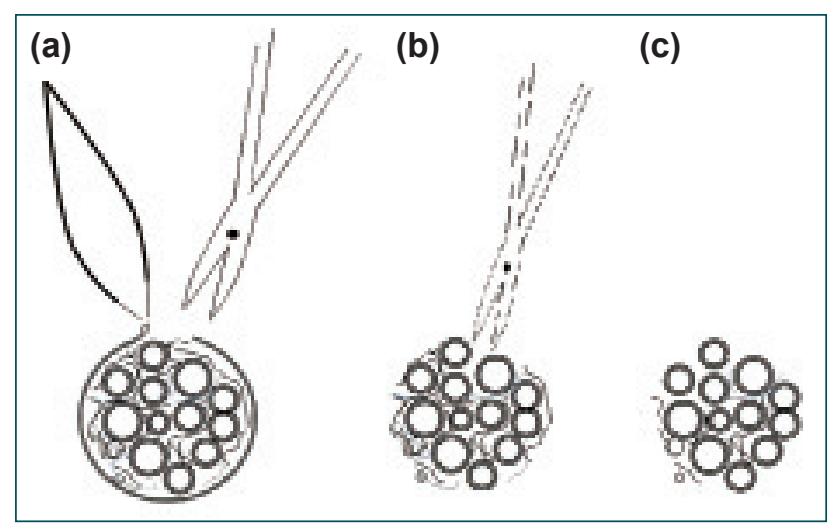

Figure 3. Internal neurolysis. (a) The external epineurium is removed using microsurgical technique. (b) The scarred internal epineurium is dissected, separating the individual fascicles, taking care not to violate the perineurium. (c) The dissected fascicles with some residual epineural scar. 
Table 2. Operation types and numbers

\begin{tabular}{|c|c|}
\hline Operation method & Number \\
\hline Ex Neu & 16 \\
\hline $\mathrm{Ex}+\ln \mathrm{Neu}$ & 5 \\
\hline $\mathrm{Ex}+\ln \mathrm{Neu}$ End to end Single $\mathrm{n}$ An & 2 \\
\hline $\mathrm{Ex}+\ln \mathrm{Neu}+$ Fasiculus An & I \\
\hline $\mathrm{Ex}+\ln \mathrm{Neu}+$ Sural $n \mathrm{G}$ of avulsed $\mathrm{C} 5$ root & I \\
\hline $\mathrm{Ex}+\ln \mathrm{Neu}+$ Neuroma Exc + Neur G & I \\
\hline $\mathrm{Ex}+\ln \mathrm{Neu}+\mathrm{IC} n$ Neurotisation & I \\
\hline
\end{tabular}

Ex: External; In: Internal; Neu: Neurolysis; An: Anastomsis; Exc: Excision; IC: Intercostal; n: Nerve; Neur: Neurogen; G: Grafting.

anastomosis was performed. The most common intraoperative finding was compression of the neural elements due surrounding fibrotic tissue. The total number of each type of operation are given in Table 2.

Patient II underwent surgery in another clinic 2 months ago before her admission to our department; it was learned that she had undergone an ulnar to second intercostal nerve anastomosis. An exploration and external neurolysis was performed in our clinic, however her intractable neuropathic pain did not resolved. An additional DREZ operation was performed for pain control, seven months later.

\section{Time Delay To Surgery}

Fifteen patients underwent surgery in less than six months following the injury, 12 patients had surgery later than six months. The patients who were operated in the first six months after trauma represented significantly better scores in DASH, SF-36 and pain scale; pre-operative pain scale scores (PSS) were similar for both groups $(p<0.05)$ (Table 4$)$.

\section{Presence of Avulsion}

Avulsion was present in three cases (Figure 4). These patients' preoperative PSS scores were significantly higher compared to the ones without avulsion. Although the preoperative scores were higher in the patients with avulsion, the long term postoperative PSS scores were not significantly different than the other group of patients (Table 5). All the parameters related with DASH and SF-36 were not significantly different between patients with and without avulsions.

\section{Localization of Injury}

When comparing the functional outcome results for different types of injuries, there was not a difference between supraclavicular, infraclavicular, or both types of injuries (Table 3).

Table 3. Patient demographics

\begin{tabular}{|c|c|c|c|c|c|c|c|c|c|c|c|}
\hline Pat. No & Age/Sex & Location & Side & $\begin{array}{l}\text { Main limitation } \\
\text { (weakness }<3 / 5 \text { ) }\end{array}$ & $\begin{array}{c}\text { Injury to } O R \\
\text { (mo) }\end{array}$ & $\begin{array}{l}\text { Foll. Up } \\
(\mathrm{mo})\end{array}$ & DASH & $\begin{array}{l}\text { SF-36 } \\
\text { PCS }\end{array}$ & $\begin{array}{l}\text { SF-36 } \\
\text { MCS }\end{array}$ & $\begin{array}{l}\text { PSS } \\
\text { Pre-op }\end{array}$ & $\begin{array}{l}\text { PSS } \\
\text { Now }\end{array}$ \\
\hline I & $50 / F$ & Supra & $R$ & $\mathrm{AAb}, \mathrm{EEb}, \mathrm{EFc}$ & 12 & 48 & 59.4 & 40.7 & 36.5 & 70 & 30 \\
\hline 2 & $5 I / M$ & Both & L & AAb, EE, EF, WE, WFc, Gc & 8 & 50 & 70.6 & 40.4 & 32.4 & 10 & 10 \\
\hline 3 & $25 / M$ & Supra & L & Flail arm & 6 & 54 & 54.3 & 44.5 & 26.5 & 10 & 10 \\
\hline 4 & $20 / M$ & Both & L & Flail arm & 5 & 68 & 70.6 & 37.5 & 22.8 & 60 & 40 \\
\hline 5 & $66 / M$ & Supra & L & Flail arm & 7 & 58 & 95.8 & 27.3 & 28.6 & 80 & 50 \\
\hline 6 & $4 I / M$ & Both & $R$ & Flail arm & 3 & 64 & 67.2 & 31.5 & 24.7 & 70 & 50 \\
\hline 7 & $47 / M$ & Infra & L & EEb & 2 & 81 & 52.5 & 39.8 & 26.8 & 30 & 70 \\
\hline 8 & $44 / M$ & Infra & L & $E E, W E, W E, G$ & 3 & 71 & 27.5 & 46.3 & 45.7 & 70 & 20 \\
\hline 9 & $10 / M$ & Supra & L & $A A b, E F, W E c$ & 9 & 102 & 39.2 & 47.5 & 47.4 & 10 & 10 \\
\hline 10 & $26 / M$ & Both & L & EE, EF, WE, WF, G & 2 & 98 & 55 & 25.0 & 34.6 & 30 & 20 \\
\hline 11 & $37 / F$ & Both & $\mathrm{R}$ & Flail arm & 6 & 120 & 68.1 & 35.1 & 22.8 & 80 & 100 \\
\hline 12 & $33 / \mathrm{F}$ & Both & L & AAbb, EEc, EF, WE, WF, G & 6 & 102 & 40 & 41.8 & 37.4 & 20 & 10 \\
\hline 13 & $26 / M$ & Supra & L & $\mathrm{AAb}, \mathrm{EE}, \mathrm{EF}, \mathrm{WEc}, \mathrm{WFc}, \mathrm{Gc}$ & 3 & 120 & 51.7 & 40.8 & 25.6 & 10 & 10 \\
\hline 14 & $18 / M$ & Supra & L & AAbb, EF, EE, WE, WF, G & 8 & 123 & 81.8 & 35.1 & 21.8 & 90 & 20 \\
\hline 15 & $46 / M$ & Infra & L & EE, EFb, WE, WF, G & 2 & 121 & 12.9 & 58.9 & 51.4 & 70 & 0 \\
\hline 16 & $23 / M$ & Both & R & $\mathrm{AAb}, \mathrm{EE}, \mathrm{EF}, \mathrm{WE}$ & 3 & 132 & 74.2 & 26.4 & 26.3 & 90 & 40 \\
\hline 17 & $15 / M$ & Supra & $\mathrm{R}$ & $\mathrm{AAb}, \mathrm{EEb}, \mathrm{EF}, \mathrm{WEc}, \mathrm{WFb}, \mathrm{Gc}$ & 2 & 159 & 29.2 & 50.2 & 48.1 & 70 & 10 \\
\hline 18 & $37 / M$ & Both & L & AAbc, EFc, WEb, WFc & 2 & 158 & 21.7 & 46.1 & 48.4 & 85 & 15 \\
\hline 19 & $24 / F$ & Both & $R$ & EEb, EFc, WE, WFb & 3 & 156 & 24.2 & 46.6 & 50 & 10 & 10 \\
\hline 20 & $28 / M$ & Supra & L & $\mathrm{AAb}, \mathrm{EEc}, \mathrm{EF}, \mathrm{WFc}$ & 4 & 34 & 20.0 & 47.0 & 41.6 & 20 & 10 \\
\hline 21 & $21 / F$ & Supra & L & $\mathrm{AAbc}, \mathrm{Gc}$ & 13 & 28 & 24.1 & 54.6 & 54.7 & 80 & 10 \\
\hline 22 & $27 / M$ & Supra & L & Flail arm & 8 & 26 & 69.8 & 36.7 & 42.9 & 40 & 40 \\
\hline 23 & $30 / M$ & Supra & L & AAb, EE, EF, WEb, WFb, Gc & 17 & 22 & 79.3 & 25.4 & 22.3 & 70 & 70 \\
\hline 24 & $30 / M$ & Both & $\mathrm{R}$ & Flail arm & 15 & 20 & 65.5 & 36.9 & 25.0 & 70 & 50 \\
\hline 25 & $44 / F$ & Supra & L & AAbb, EE, EF, WE, WF & 12 & 17 & 81.8 & 35.3 & 22.8 & 90 & 90 \\
\hline 26 & $20 / M$ & Supra & $\mathrm{R}$ & $\mathrm{EEb}, \mathrm{EFb}, \mathrm{WEc}$ & 5 & 19 & 18.1 & 48.3 & 43.3 & 60 & 20 \\
\hline 27 & $17 / F$ & Supra & L & AAbb, WFc, WE, G & 12 & 98 & 26.7 & 47.5 & 47.6 & 30 & 10 \\
\hline
\end{tabular}

R: Right; L: Left; Supra: Supraclavicular; Infra: Infraclavicular; M: Male; F: Female; mo: Months; DASH: Disability of the Arm, Shoulder and Hand; SF-36: Short Form 36; PCS: Physical component summary; MCS: Mental component summary; OR: Operation; AAb: Abduction of the arm; EE: Elbow extension; EF: Elbow flexion; WF: Wrist flexion; WE: Wrist extension; G: Grip; bPower was 3/5, cPower was 4/5. 


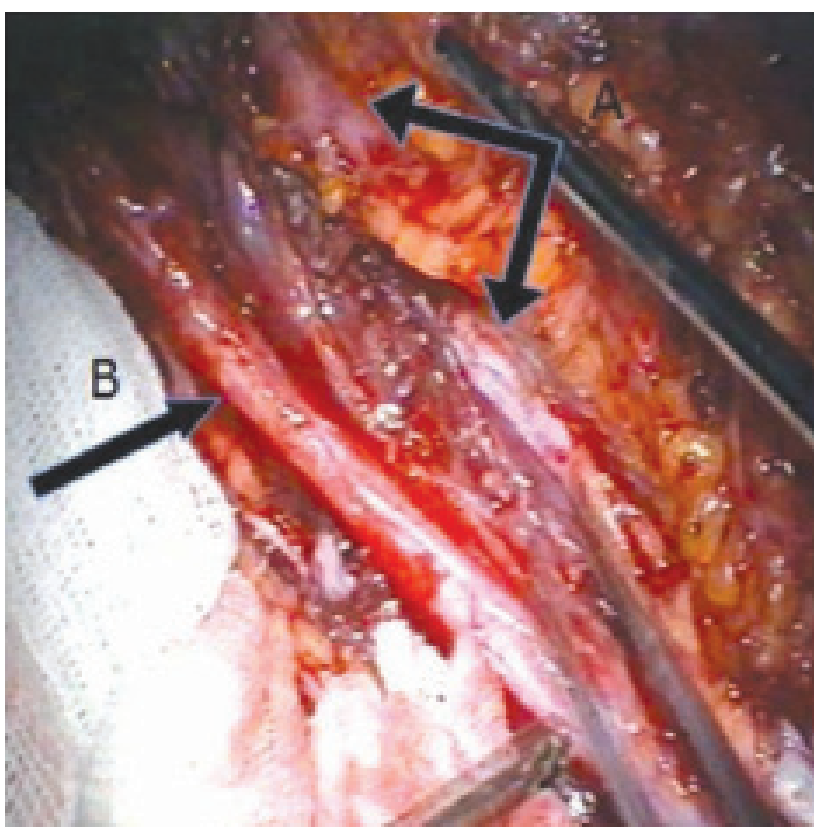

Figure 4. Operation photograph of a patient with penetrating glass injury. A. Two tips of the avulsed upper truncus. B. Middle truncus.

\section{The Effect of Weakness on Outcome}

For analyzing the effect of preoperative weakness on outcome; the patients were grouped to two groups; patients having BMRC grade 0/5, I/5, 2/5 and patients having BMRC grade $3 / 5,4 / 5,5 / 5$ for each muscle group. Deltoid, triceps, biceps, wrist flexors, wrist extensors and distal interosseous muscle group's strengths were evaluated. For only the distal interosseous muscle group, it was found that patients having muscle strength less than 3/5 preoperatively have significantly worse results for post PSS 0.03 (Mann-Whitney U). There was not a statistically significantly difference for DASH and SF-36 scores.

\section{The Effect of Additional Injuries}

Six patients had additional injuries other than Brachial Plexus Injury. The presence of additional injuries did not significantly change the scores of the DASH, SF-36 and PSS assessments.

\section{Side}

There were 8 patients with right side TBPI and 19 patients with left side TBPI. All of the patients were right handed. No statistical differences were seen between the two groups on the DASH or SF-36 scores. Neither questionnaire focuses on the side of the injury. Answers are based on the ability to perform the activity, regardless of how the activity was performed. So there is potential bias for the patients with an injury on the nondominant side. This is a particular concern in the DASH questionnaire, as the questions had been chosen for those tasks in which both hands/arms/shoulders must be used like " Can you open a tight or new jar?" or " Can you use a knife to cut food? ". Another aspect of this study is to determine the effect of TBPI surgery's effect on the life of the patient. So, comparing the right and left side would also be important from this point of view. It is possible that a greater number of patients are needed to make an objective comparison, because not all of the right and left dominant patients had a homogenous distribution. But according to these results, as all of the patients were right hand dominant, left sided BPI patients had better results than the opposite side.

\section{DISCUSSION}

With the contribution of modern technology to the medi-

Table 4. Mann-Whitney $U$ test

\begin{tabular}{lccc}
\hline & $\begin{array}{c}\text { Patients operated in 0-6 months of injury } \\
\text { (Mean } \pm \text { SD) }\end{array}$ & $\begin{array}{c}\text { Patients operated after } \mathbf{6} \text { months of injury } \\
\text { (Mean } \pm \text { SD) }\end{array}$ \\
\hline DASH & $42.2 \pm 21.6$ & $62.4 \pm 22.6$ & p \\
PCS (SF-36) & $51.3 \pm 7.0$ & $41.8 \pm 9.4$ & 0.026 \\
MCS (SF-36) & $46.9 \pm 12.0$ & $39.4 \pm 11.9$ & 0.015 \\
Pre-op APS & $55.3 \pm 30.5$ & $55.9 \pm 29.9$ & 0.032 \\
Post-op APS & $13.0 \pm 5.9$ & $34.1 \pm 26.4$ & 0.173 \\
\hline
\end{tabular}

DASH: Disability of the Arm, Shoulder and Hand; SF-36: Short Form 36; PCS: Physical component summary; MCS: Mental component summary; APS: Analog pain scale.

Table 5. Mann-Whitney $U$ test

\begin{tabular}{|c|c|c|c|}
\hline & $\begin{array}{c}\text { Patients with avulsion } \\
(\text { Mean } \pm S D)\end{array}$ & $\begin{array}{l}\text { Patients without avulsion } \\
\text { (Mean } \pm \text { SD) }\end{array}$ & $\mathbf{p}$ \\
\hline Pre-op analog pain scale & $85.0 \pm 8.7$ & $51.9 \pm 29.4$ & 0.029 \\
\hline Post-op analog pain scale & $13.3 \pm 5.8$ & $23.5 \pm 21.7$ & 0.463 \\
\hline
\end{tabular}


cine, a parallel increase is obtained in the success of peripheral nerve surgery. The usage of an operating microscope has increased the success rates in all divisions of neurosurgery including peripheral nerve surgery. TBPI lesions are mostly seen in young adults who were otherwise healthy and this injury limits the social and professional life of the victim.

As a common mistake of physicians, we generally consider the objective findings of the patients like muscle strength and sensory performance instead of subjective symptoms like pain or feeling of well-being. But a patient may have a normal motor and sensory function with intractable pain. In contrast, a patient's severe pain may be relieved but his/her motor status may not improve. Thus, when evaluating the success of a surgical procedure, like BPI surgery, we must also take into account the subjective changes in the patients' feelings such as pain status, emotional state and desire to return to work.

There are few studies regarding TBPI patients' functional outcomes, feelings and $\mathrm{QOL}$ in the literature. ${ }^{[2,10,11]}$ There is an increased need for evaluating the QOL of these patients. In this study we want to represent our clinical experience with analyzing our patients' QOL assessment.

Compatible with the literature ${ }^{[2,6,25-27]}$ the results of this study demonstrated that patients who underwent surgery for BPI within the first six months of injury have better functional outcomes compared with patient who waited longer. In the current series, patients operated in the first six months of trauma scored significantly better results in SF36, DASH and PSS assessments.

According to our clinical practice, immediate surgery, without waiting for electrophysiological evaluation should be performed on the patients who had a penetrating TBPI. Neurologists who carry out electrophysiological tests recommend to perform these tests 21 days after trauma. ${ }^{[28,29]}$ The initial three weeks of healing prior to testing theoretically decreases testing artefacts. In the light of these data, we think the best timing for a blunt BPI surgery is between 3 weeks and 6 months after trauma. Perhaps future studies can be designed to investigate the comparable outcomes of patients operated in the first 3 months and 4th to 6th months of trauma.

In the present study, the mean time from trauma to surgery was 6.6 months. Considering that the six month window is a critical period for a BPI patient to undergo surgery, referral of these patients needs to be improved. This is a common problem involving both patients and physicians in treatment of TBPI. ${ }^{[2,6]}$ An epidemiological study by Midha stated that $78 \%$ of multitrauma patients with BPI were diagnosed within the first 3 days of injury. ${ }^{[30]}$ Thus, this problem may be overcome by increasing the awareness of this pathology among the physicians in other disciplines who infrequently encounter this pathology. Flores stated that they improved this problem by means of workshops and discussions related to the necessity of early investigation of the cases among other physicians. ${ }^{[27]}$

Some authors, like Magalon et al., ${ }^{[3 !]}$ advocate for very early surgery for TBPI patients, as they believe regardless of associated vascular or bone injuries, brachial plexus lesions should be repaired within the first 7 days after injury. They stated that it is easier to operate early because relatively shorter grafts can be used. While this can be true for penetrating injuries, some patients may be unnecessarily operated on due to the inability to perform neurophysiological tests in the early days after injury. ${ }^{[6,31]}$

From the point of localization, there is a debate in the literature. Some authors stated that supraclavicular elements are injured more severely and have a worse prognosis. ${ }^{[30,32]}$ Whereas others disagree with this argument. ${ }^{[6,11]}$ We did not find a significant difference between the SF-36, DASH and APS scores of patients with supraclavicular, infraclavicular or mixed type of injury localization.

Flores advocated that normal or near normal post-traumatic motor function status of the hand is one of the most important preoperative parameters for obtaining good outcomes. [27] For the current study this was not the case. The preoperative strength of each muscle group were analyzed according to the scores the patients reported and there was not a significant difference in any muscle group for PSS/DASH/SF-36 assessments.

The preoperative PSS of the patients with avulsions were significantly higher compared to the ones without avulsion. Although their preoperative scores were higher, the long term postoperative PSS were not significantly different than the patients without avulsion. This finding is concordant with the results of Labib's studies. ${ }^{[2]}$ They also found that patients with avulsions had worse scores for pain and SF-36.

Since this main tissue which is strived on is nerve, evaluation of the success of the TBI surgery must depend on long follow-up periods. This period is estimated as 2-3 years according to some authors ${ }^{[5,33]}$ and 4 years for others. ${ }^{[34]}$ The mean follow-up period for the current study is 79 months which is quite long enough.

According to our experience, patients who were operated for BPI benefit more from the point of pain than muscle strength. In other words, patients who were underwent surgery may not have a significant improvement in their muscle strength but they have significantly less pain after the operation. This was also stressed in the previous literature. ${ }^{\left[{ }^{11}\right]}$ The importance of informing patients about this issue preoperatively is important in providing an adequate expectation and satisfaction from the operation and prevent frustration..$^{[1]}$ 
One of the limitations of the present study is the absence of preoperative SF-36 and DASH scores of the patients, ideally these scores could be compared with current scores. Also, another limitation of this study is the lack of current neurological examination of the patients, as we do not exactly know their muscle strengths.

All of the patients at least had an external neurolysis procedure in this study. Only a small number of patients had nerve grafting. Comparing with the literature, our rate of grafting is lower than the average. We attributed this finding to late referral. The mean time for admission from injury was 6.6 months in the present study. We believe nerve grafting is more efficient when performed shortly after injury, thus, in our patients who were referred months after injury, nerve grafting was performed only for a small number. Nevertheless, external neurolysis was performed for the management of pain in all cases. The importance of delayed referral of BPI patients to specialized centers has been stressed in previous literature. ${ }^{[6,35,36]}$

Norkus et al. ${ }^{[26]}$ published a study of 14 patients and concluded that neurolysis or nerve transfer in the early stage (first 12 months) and tendon transfer in the late stage of brachial plexus injury may result in significant improvement. In the present study, there is an insufficient number of patients for comparing the operation methods as only three patients underwent an anastomosis, two patients underwent nerve transfers and one patient underwent neurotisation.

Studies examining the correlation between patient's self-assessment and physician's examination can be designed in the future.

\section{Conclusions}

Statistically validated tests like SF-36 and DAS questionnaires are valuable tools for evaluating the BPI patients. Specialized centers dealing with TBPI surgery may use these tests preand postoperatively which will lead to an objective personalized evaluation of each patient's subjective symptoms.

\section{Acknowledgements}

The present work was not supported by any fund or organization.

\section{REFERENCES}

1. Kim DH, Cho YJ, Tiel RL, Kline DG. Outcomes of surgery in 1019 brachial plexus lesions treated at Louisiana State University Health Sciences Center. J Neurosurg 2003;98:1005-16. [CrossRef ]

2. Ahmed-Labib M, Golan JD, Jacques L. Functional outcome of brachial plexus reconstruction after trauma. Neurosurgery 2007;61:1016-23.

3. Ricardo M. Surgical treatment of brachial plexus injuries in adults. Int Orthop 2005;29:351-4. [CrossRef ]
4. Millesi H. Surgical management of brachial plexus injuries. J Hand Surg Am 1977;2:367-78. [CrossRef]

5. Narakas A. Brachial plexus surgery. Orthop Clin North Am 1981;12:30323.

6. Dubuisson AS, Kline DG. Brachial plexus injury: a survey of 100 consecutive cases from a single service. Neurosurgery 2002;51:673-83.

7. Kandenwein JA, Kretschmer T, Engelhardt M, Richter HP, Antoniadis G. Surgical interventions for traumatic lesions of the brachial plexus: a retrospective study of 134 cases. J Neurosurg 2005;103:614-21. [CrossRef ]

8. Kline DG, Tiel RL. Direct plexus repair by grafts supplemented by nerve transfers. Hand Clin 2005;21:55-69. [CrossRef ]

9. Secer HI, Solmaz I, Anik I, Izci Y, Duz B, Daneyemez MK, et al. Surgical outcomes of the brachial plexus lesions caused by gunshot wounds in adults. J Brachial Plex Peripher Nerve Inj 2009;4:11. [CrossRef ]

10. Choi PD, Novak CB, Mackinnon SE, Kline DG. Quality of life and functional outcome following brachial plexus injury. J Hand Surg Am 1997;22:605-12. [CrossRef]

11. Kretschmer T, Ihle S, Antoniadis G, Seidel JA, Heinen C, Börm W, et al. Patient satisfaction and disability after brachial plexus surgery. Neurosurgery 2009;65:189-96. [CrossRef ]

12. Solway S, Beaton DE, McConnell S, Bombardier C. The DASH outcome measure user's manual. 2nd ed. Toronto: Institute for Work \& Health; 2002.

13. Beaton DE, Davis AM, Hudak P, McConnell S. The DASH (Disabilities of the Arm, Shoulder and Hand) outcome measure: what do we know about it now? British Journal of Hand Therapy 2001;6:109-18.

14. About the DASH. http://www.dash.iwh.on.ca/about.htm. Accessed February 25, 2006.

15. McHorney CA, Ware JE Jr, Lu JF, Sherbourne CD. The MOS 36-item Short-Form Health Survey (SF-36): III. Tests of data quality, scaling assumptions, and reliability across diverse patient groups. Med Care 1994;32:40-66. [CrossRef ]

16. McHorney CA, Ware JE Jr, Raczek AE. The MOS 36-Item ShortForm Health Survey (SF-36): II. Psychometric and clinical tests of validity in measuring physical and mental health constructs. Med Care 1993;31:247-63. [CrossRef]

17. Hunsaker FG, Cioffi DA, Amadio PC, Wright JG, Caughlin B. The American academy of orthopaedic surgeons outcomes instruments: normative values from the general population. J Bone Joint Surg Am 2002;84-2:208-15.

18. Ware JE Jr, Sherbourne CD. The MOS 36-item short-form health survey (SF-36). I. Conceptual framework and item selection. Med Care 1992;30:473-83. [CrossRef]

19. Birch R, Bonney G, Wynn Parry CB. Surgical disorders of the peripheral nerves. Edinburgh: Churchill Livingstone; 1998.

20. Kline DG, Hudson AR. Nerve injuries: operative results for major nerve injuries, entrapments, and tumors. Philadelphia: W.B. Saunders; 1995.

21. Leffert RD. Brachial plexus injuries. New York: Churchill Livingstone; 1985.

22. Davis DH, Onofrio BM, MacCarty CS. Brachial plexus injuries. Mayo Clin Proc 1978;53:799-807.

23. Kline DG, Judice DJ. Operative management of selected brachial plexus lesions. J Neurosurg 1983;58:631-49. [CrossRef ]

24. Burchiel KJ, Ochoa JL. Surgical management of post-traumatic neuropathic pain. In: Burchiel KJ, editor. Neurosurgery Clinics of North America. Surgical Management of Peripheral Nerve Injury and Entrapment. Philadelphia: W.B. Saunders; 1991. p. 117-21.

25. Jivan S, Kumar N, Wiberg M, Kay S. The influence of pre-surgical delay 
on functional outcome after reconstruction of brachial plexus injuries. J Plast Reconstr Aesthet Surg 2009;62:472-9. [CrossRef]

26. Norkus T, Norkus M, Pranckevicius S, Pamerneckas A, Zobakas A, Vizgirda A. Early and late reconstruction in brachial plexus palsy: a preliminary report. Medicina (Kaunas) 2006;42:484-91.

27. Flores LP. The importance of the preoperative clinical parameters and the intraoperative electrophysiological monitoring in brachial plexus surgery. Arq Neuropsiquiatr 2011;69:654-9. [CrossRef ]

28. Bufalini C, Pescatori G. Posterior cervical electromyography in the diagnosis and prognosis of brachial plexus injuries. J Bone Joint Surg Br 1969;51:627-31.

29. Grant GA, Goodkin R, Kliot M. Evaluation and surgical management of peripheral nerve problems. Neurosurgery 1999;44:825-40. [CrossRef]

30. Midha R. Epidemiology of brachial plexus injuries in a multitrauma population. Neurosurgery 1997;40:1182-9. [CrossRef ]
31. Magalon G, Bordeaux J, Legre R, Aubert JP. Emergency versus delayed repair of severe brachial plexus injuries. Clin Orthop Relat Res 1988;237:32-5.

32. Narakas AO. The treatment of brachial plexus injuries. Int Orthop 1985;9:29-36. [CrossRef]

33. Terzis JK, Papakonstantinou KC. The surgical treatment of brachial plexus injuries in adults. Plast Reconstr Surg 2000;106:1097-1124.

34. Samii M, Carvalho GA, Nikkhah G, Penkert G. Surgical reconstruction of the musculocutaneous nerve in traumatic brachial plexus injuries. J Neurosurg 1997;87:881-6. [CrossRef ]

35. Kanaya F, Gonzalez M, Park CM, Kutz JE, Kleinert HE, Tsai TM. Improvement in motor function after brachial plexus surgery. J Hand Surg Am 1990;15:30-6. [CrossRef ]

36. McGillicuddy JE. Clinical decision making in brachial plexus injuries. Neurosurg Clin N Am 1991;2:137-50.

\section{KLINIKK ÇALIŞMA - ÖZET}

\section{Travmatik brakiyal plesus yaralanmaları cerrahisi sonrası fonksiyonel sonuçlar: Klinik çalışma}

Dr. Yavuz Aras, Dr. Aydın Aydoseli, Dr. Pulat Akın Sabancı, Dr. Mehmet Osman Akçakaya, Dr. Görkem Alkır, Dr. Murat İmer

İstanbul Üniversitesi İstanbul Tıp Fakültesi, Nöroşirürji Anabilim Dalı, İstanbul

AMAÇ: Bu çalışmanın amacı istatistiksel geçerliliği olan değerlendirme araçları kullanılarak fonksiyonel sonuçları ve hastaların yaşam kalitesini incelemektir.

GEREÇ VE YÖNTEM: Hastalar telefon ile arandı. Kısa form-36 (SF-36), el-kol ve omuz maluliyet değerlendirme anketi (DASH), bir ağrı derecelendirme testi hastalar tarafindan dolduruldu ve hastaların uygulanan cerrahi ile ilgili memnuniyeti sorgulandı.

BULGULAR: i.Ü. İstanbul Tıp Fakültesi, Nöroşirürji Kliniği'nde 1997-20I0 yılları arasında travmatik brakiyal pleksus yaralanması (TBPY) tanısılla toplam 33 hasta tek bir cerrah tarafından (MI) ameliyat edildi. Üç hasta değerlendirmeye katılmayı reddetti ve üç hasta çalışmaya alınmadı. Toplamda 27 hasta, ortalama 79.6 aylık takip süresi ile çalışmaya alındı. TBPY'nin en sık nedeni motorlu araç kazaları idi. On dört hastada izole supraklaviküler, üç hastada ise infraklaviküler yaralanma vardı. Kalan 10 hastada yaralanmalar hem supra- hem infraklavikülerdi. Üç hastada kök avülsiyonuna rastlandı. Travma sonrası ilk altı ay içinde ameliyat edilen hastaların SF-36, DASH testleri ve ağrı dereceleri, diğer hastalara göre belirgin şekilde daha iyi olarak bulundu.

TARTIŞMA: SF-36 ve DASH gibi istatistiksel geçerliliği olan testler TBPY hastalarının değerlenmesinde kullanılabilecek değerli araçlardır. TBPY ile ilgilenen özelleşmiş merkezler için, bu testlerin ameliyat öncesi ve sonrası dönemde uygulanmasıyla hastaların öznel şikayetlerinin nesnel olarak değerlendirilmesi mümkündür.

Anahtar sözcükler: Brakiyal pleksus; fonksiyonel sonuçlar; sinir yaralanması; yaşam kalitesi.

Ulus Travma Acil Cerr Derg 2013;19(6):521-528 doi: 10.5505/tjtes.2013.48107 